G. D. Slipchenko, V. O. Hrudko, O. A. Ruban

National University of Pharmacy

\title{
Development of the methods for spectrophotometric determination of the flavonoid concentration in solution to study bioavailability of the amount of bioactive substances in capsules containing the powder of Scutellaria baikalensis roots and rhizomes
}

Recently, the test "Dissolution", which allows evaluating bioavailability of active ingredients, has become one of the most important tools in the quality control of new and generic drugs development ("biowaiver" procedure). However, for some drugs the use of classical pharmacopoeia buffer solutions in vitro does not always completely adequately reflect their behavior in vivo. As a solution of this problem the group of biorelevant media, which allow simulating dissolution and adsorption of drugs in the gastrointestinal tract of a patient, has been developed.

Aim. To develop the methods of spectrophotometric determination of the flavonoid concentration in $0.1 \mathrm{M}$ hydrochloric acid solution and biorelevant media FaSSIF and FeSSIF with pH 6.5 and 6.8 calculated with reference to baicalin for further study of bioavailability of hard gelatine capsules containing a finely divided powder of Scutellaria baicalensis roots and rhizomes.

Materials and methods. For the studies on bioavailability determination of pharmacologically active substances of a finely divided powder of Scutellaria baicalensis roots and rhizomes the method of absorption spectrophotometry in the ultraviolet and visible regions of the spectrum calculated with reference to baicalin was chosen.

Results and discussion. Adsorption spectra of baicalin solutions in $0.1 \mathrm{M}$ hydrochloric acid solution and biorelevant media FaSSIF (pH 6.5) and FeSSIF (pH 6.8) in the range from 230 to $370 \mathrm{~nm}$ consist of two absorption bands. The band with the maximum at $276 \mathrm{~nm}$ is more intense, while the band in the near ultraviolet region is less intensive, but broader. The use of this maximum for quantification will allow increasing the specificity of the analysis. The analysis of adsorption spectra of the solutions obtained during extraction of the powder from Scutellaria baicalensis roots and rhizomes with $0.1 \mathrm{M}$ hydrochloric acid solution and biorelevant media FaSSIF and FeSSIF with $\mathrm{pH} 6.5$ and $\mathrm{pH} 6.8$ has shown that their structure is virtually the same as the spectral structure of baicalin solutions. In order to test the possible impact of the dissolution media on the total optical density at the analytical wavelength the adsorption spectra of the biorelevant media FaSSIF and FeSSIF with pH 6.5 or 6.8 have been studied. The analysis of the data obtained has shown that the media are really nontransparent in ultraviolet light and have quite intensive absorption in the range of 230-290 $\mathrm{nm}$. The absorbance testing of baicalin solutions in $0.1 \mathrm{M}$ hydrochloric acid solution and biorelevant media FaSSIF and FeSSIF with pH 6.5 and $\mathrm{pH} 6.8$ has shown that the dependence is linear and obeys the Beer-Lambert law in the range of the concentration from 0.4 to $3.6-4.0 \cdot 10^{-3} \%$.

Conclusions. To develop the method for determining the concentration of solutions of pharmacologically active substances while studying bioavailability of capsules containing a finely divided powder of Scutellaria baicalensis roots and rhizomes the adsorption spectra of baicalin in $0.1 \mathrm{M}$ hydrochloric acid solution and biorelevant media FaSSIF and FeSSIF with pH of 6.5 and 68 have been studied.

Key words: adsorption spectroscopy; baicalin; flavonoids; capsules; Scutellaria baicalensis; biorelevant media

\author{
Г. Д. Сліпченко, В. О. Грудько, О. А. Рубан
}

Розробка методики спектрофотометричного визначення концентрації розчинів фллавоноїдів для вивчення біодоступності суми біологічно активних речовин у капсулах 3 порошком коренів та кореневищ шоломниці байкальської

Останнім часом тест «Розчинення», який дозволяє оцінити біодоступність діючих речовин, став одним 3 найважливіших інструментів у галузі контролю якості розробки нових і відтворення патентованих лікарських засобів (ЛЗ) (процедура «біовейвер»). Однак для деяких ЛЗ застосування класичних фрармакопейних буферних розчинів in vitro не завжди повністю адекватно відображає їх поведінку in vivo. Тому для моделювання процесу розчинення у шлунково-кишковому тракті доцільно використовувати групу біорелевантних середовищ (biorelevant media).

Мета роботи. Розробити методики спектрофотометричного визначення концентрації розчинів фрлавоноїдів у 0,1 М розчині кислоти і біорелевантних середовищах FaSSIF i FeSSIF з pH 6,5 і 6,8 у перерахунку на байкалін для подальшого вивчення біодоступності твердих желатинових капсул з подрібненим порошком коренів та кореневищ шоломниці байкальської. 
Матеріали та методи. Для проведення досліджень із визначення біодоступності фрармакологічно активних речовин подрібненого порошку коренів та кореневищ шоломниці байкальської було обрано метод адсорбційної спектрофотометрії в ультрафіолетовій і видимих областях спектра з перерахунком їх вмісту на байкалін.

Результати та їх обговорення. Адсорбційні спектри розчинів байкаліну в 0,1 М розчині хлористоводневої кислоти та біорелевантних середовищах FaSSIF з pH 6,5 i FaSSIF з pH 6,8 в області спектра від 230 до 370 нм складаються з двох смуг поглинання. Смуга з максимумом при 276 нм є більш інтенсивною, смуга в ближньому ультрафрілеті $є$ менш інтенсивною, але ширшою. Використання цього максимуму для кількісного визначення дозволить підвищити специфічність аналізу. Аналіз адсорбційних спектрів розчинів, отриманих під час екстракції порошку коренів та кореневищ шоломниці байкальської 0,1 М розчином хлористоводневої кислоти і біорелевантними середовищами FaSSIF i FeSSIF з рH 6,5 та pH 6,8, показує, що їх структура практично повторює структуру спектрів розчинів байкаліну. 3 метою перевірки можливого впливу середовищ розчинення на сумарну оптичну густину за аналітичної довжини хвилі досліджені адсорбційні спектри біорелевантних середовищ FaSSIF i FeSSIF з рH 6,5 або 6,8. Аналіз отриманих даних показав, що дійсно середовища не прозорі для ультрафіолетового світла і мають досить інтенсивне поглинання в області 230-290 нм. Перевірка підпорядкування світлопоглинання розчинів байкаліну в 0,1 М розчині хлористоводневої кислоти та біорелевантних середовищах FaSSIF i FeSSIF з pH 6,5 та pH 6,8 показала, що залежність носить лінійний характер і відповідає закону БугераЛамберта-Бера в діапазоні досліджених концентрацій від 0,4 до 3,6-4,0 · 10-3 \%.

Висновки. 3 метою розробки методики визначення концентрації розчинів фрармакологічно активних речовин під час вивчення біодоступності капсул з подрібненим порошком коренів та кореневищ шоломниці байкальської були вивчені адсорбційні спектри розчинів байкаліну в 0,1 М розчині хлористоводневої кислоти і біорелевантних середовищах FaSSIF i FeSSIF з pH 6,5 і 6,8.

Ключові слова: адсорбційна спектрофотометрія; байкалін; фрлавоноїди; капсули; шоломниця байкальська; біорелевантні середовища

\section{Г. Д. Слипченко, В. А. Грудько, Е. А. Рубан}

\section{Разработка методик спектрофоотометрического определения концентрации растворов фрлавоноидов для изучения биодоступности суммы биологически активных веществ в капсулах с порошком корней и корневищ шлемника байкальского}

В последнее время тест «Растворение», который позволяет оценить биодоступность действующих веществ, стал одним из важнейших инструментов в области контроля качества новых и воспроизведения патентованных лекарственных препаратов (ЛП) (процедура «биовейвер»). Однако для некоторых ЛС применение классических фрармакопейных буферных растворов in vitro не всегда полностью адекватно отражает их поведение in vivo. Поэтому для моделирования процесса растворения в желудочно-кишечном тракте целесообразно использовать группу биорелевантных сред (biorelevant media).

Цель работы. Разработать спектрофотометрические методики определения концентрации растворов фрлавоноидов в 0,1 М растворе кислоты соляной и биорелевантных средах FaSSIF и FeSSIF c pH 6,5 и 6,8 в пересчете на байкалин для дальнейшего изучения биодоступности твердых желатиновых капсул с измельченным порошком корней и корневищ шлемника байкальского.

Материалы и методы. Для проведения исследований по определению биодоступности фрармакологически активных веществ измельченного порошка корня шлемника байкальского был выбран метод адсорбционной спектрофотометрии в ультрафиолетовой и видимой областях спектра с пересчетом их содержания на байкалин.

Результаты и их обсуждение. Адсорбционные спектры растворов байкалина в 0,1 М растворе соляной кислоты и биорелевантных средах FaSSIF c pH 6,5 и FaSSIF c pH 6,8 в области от 230 до 370 нм состоят из двух полос поглощения. Полоса с максимумом при 276 нм более интенсивная, полоса в ближнем ультрафиолете менее интенсивная, но более широкая. Использование этого максимума для количественного определения позволит повысить специфичность анализа. Анализ адсорбционных спектров растворов, полученных при экстракции порошка корней и корневищ шлемника байкальского 0,1 М раствором соляной кислоты и биорелевантными средами FaSSIF и FeSSIF c pH 6,5 и pH 6,8, показывает, что их структура практически повторяет структуру спектров растворов байкалина. С целью проверки возможного влияния сред растворения на суммарную оптическую плотность при аналитической длине волны мы исследовали адсорбционные спектры биорелевантных сред FaSSIF и FeSSIF c pH 6,5 или 6,8. Анализ полученных данных показал, что действительно среды не прозрачны для ультрафиолетового света и имеют достаточно интенсивное поглощение в области спектра 230-290 нм. Проверка подчинения светопоглощения растворов байкалина в 0,1 М растворе соляной кислоты и биорелевантных средах FaSSIF и FeSSIF c pH 6,5 и pH 6,8 показала, что зависимость носит линейный характер и соответствует закону Бугера-Ламберта-Бера в диапазоне исследованных концентраций от 0,4 до $3,6-4,0 \cdot 10^{-3} \%$.

Выводы. С целью разработки методики определения концентрации растворов фрармакологически активных веществ при изучении биодоступности капсул с измельченным порошком корней и корневищ шлемника байкальского были изучены адсорбционные спектры растворов байкалина в 0,1 М растворе соляной кислоты и биорелевантных средах FaSSIF и FeSSIF с pH 6,5 и 68.

Ключевые слова: адсорбционная спектрофотометрия; байкалин; фрлавоноиды; капсулы; шлемник байкальский; биорелевантные среды 
Recently, the test "Dissolution", which allows evaluating bioavailability of active ingredients, has become one of the most important tools in the quality control of new and generic drugs development ("biowaiver" procedure) [1-4]. However, for some drugs the use of classical pharmacopoeia buffer solutions in vitro does not always completely adequately reflect their behavior in vivo. As a solution of this problem the group of biorelevant media, which allow simulating dissolution and adsorption of drugs in the gastrointestinal tract of a patient, has been developed [5-8].

The aim of the work was to develop the methods of spectrophotometric determination of the flavonoid concentration in $0.1 \mathrm{M}$ hydrochloric acid solution and biorelevant media FaSSIF and FeSSIF with pH 6.5 and 6.8 calculated with reference to baicalin for further study of bioavailability of hard gelatine capsules containing a finely divided powder of Scutellaria baicalensis roots and rhizomes.

To achieve this goal it was necessary to study the adsorption spectra of baicalin and the extracts obtained from the powder of Scutellaria baicalensis roots and rhizomes to identify the analytical absorption band - a considerably intense peak without absorption of other components of the analytical system and to set limits of absorbance subordination to Bouguer-Lambert-Beer law in order to conduct further research on studying bioavailability of biologically active substances in the capsules containing the powder of Scutellaria baicalensis roots and rhizomes $[9,10]$.

\section{Materials and methods}

The biological activity of the plant raw material is usually caused not by one active ingredient, but a group of pharmacologically active compounds of the similar structure. Determination of the content of such substances is carried out by the non-specific method based on the common fragments of the structure, and the determination results are recalculated for the most decisive marker compound. For the studies on bioavailability determination of pharmacologically active substances of a finely divided powder of Scutellaria baicalensis roots and rhizomes the method of absorption spectrophotometry in the ultraviolet and visible regions of the spectrum calculated with reference to baicalin was chosen.

In order to select the analytical absorption peak the absorption spectra of baicalin in $0.1 \mathrm{M}$ hydrochloric acid solution simulating the acidic medium of the gastric juice were studied, and then in biorelevant media FaSSIF and FeSSIF with pH 6.5 and 6.8 modeling the processes in the intestine. The accurately weighed quantity of $0.0501 \mathrm{~g}$ of baicalin standard sample (SS) was placed in a $50 \mathrm{ml}$ volumetric flask, then $1 \mathrm{ml}$ of dimethylformamide was added. The content of the flask was mixed to dissolution and diluted to the volume with $96 \%$ ethanol (solution A). In $100 \mathrm{ml}$ volumetric flask $1 \mathrm{ml}$ of solution A was placed, diluted to the volume with $0.1 \mathrm{M}$ hydrochloric acid solution or buffer solution of FaSSIF with $\mathrm{pH} 6.5$ or FeSSIF with pH 6.8 and thoroughly mixed. Adsorption spectra of the resulting solution were recorded using an Evolution 60-S spectrophotometer in the cells with the layer thickness of $10 \mathrm{~mm}$. As a control solution the corresponding solvent was used.

In order to test the effect of all extractives on the total extract absorption spectrum and the possibility of quantitative determination of flavonoids in the study of solubility of biologically active substances of the powder from Scutellaria baicalensis roots and rhizomes the adsorption spectra of the solutions obtained by extraction of the powder with $0.1 \mathrm{M}$ hydrochloric acid solution or biorelevant media FaSSIF and FeSSIF with $\mathrm{pH}$ 6.5 and 6.8 were investigated. Approximately $0.297 \mathrm{~g}$ of the test samples of the powder from Scutellaria baicalensis roots and rhizomes (accurate weight) differed by powder fineness were quantitatively transferred to a $250 \mathrm{ml}$ conical flask with a ground glass stopper, then $100.0 \mathrm{~mL}$ of $0.1 \mathrm{M}$ hydrochloric acid solution or biorelevant media FaSSIF and FeSSIF with pH 6.5 or 6.8 were added. The flask was placed in a thermostat with the temperature of $37 \pm 2{ }^{\circ} \mathrm{C}$ on a device for shaking and stirred for one hour. The resulting extracts were filtered through a "blue ribbon" paper filter; the first portions of filtrate were discarded. As a control solution $0.1 \mathrm{M}$ hydrochloric acid solution or biorelevant media FaSSIF and FeSSIF of pH 6.5 or 6.8 were used.

Biorelevant media were prepared by the formulations given in the literature [4].

Surfactants lecithin and sodium taurocholate in the composition of the media can be nontransparent to ultraviolet light, their maxima interacting with extractive substances can shift, affect the total absorption of solutions and distort the results of the research. Adsorption spectra of the media were observed under the same conditions compared to water.

One of the conditions that must be met for quantitative measurements in spectrophotometry is absorbance subordination of the solutions analyzed to Beer-Lambert law. The required amount of solution A was placed in a $25 \mathrm{ml}$ volumetric flask, diluted to the volume with the corresponding buffer solution and mixed. The absorbance of the resulting solution was measured using an Evolution 60-S spectrophotometer at a wavelength of $\lambda_{\max } 317 \mathrm{~nm}$ in the cells with the layer thickness of $10 \mathrm{~mm}$. As a control solution the corresponding solution of $0.1 \mathrm{M}$ hydrochloric acid or biorelevant media FaSSIF and FeSSIF with pH 6.5 or 6.8 was used.

\section{Results and discussion}

Adsorption spectra of baicalin in $0.1 \mathrm{M}$ hydrochloric acid solution and biorelevant media FaSSIF ( $\mathrm{pH}$ 6.5) and FeSSIF ( $\mathrm{pH}$ 6.8) in the wavelength range from 230 to $370 \mathrm{~nm}$ consist of two absorption bands (Fig. 1).

The band with the maximum at $276 \mathrm{~nm}$ is more intense; in this region most aromatic compounds absorb. The band in the near ultraviolet region is less intensive, but broader. Its maximum at $317 \mathrm{~nm}$ is in the range where typically flavonoids absorb, while other aromatic compounds do not absorb already, or their absorbance is not substantial. The use of this maximum for quantification will allow increasing the specificity of the analysis.

The analysis of adsorption spectra of the solutions (Fig. 2) obtained during extraction of the powder from Scutellaria 


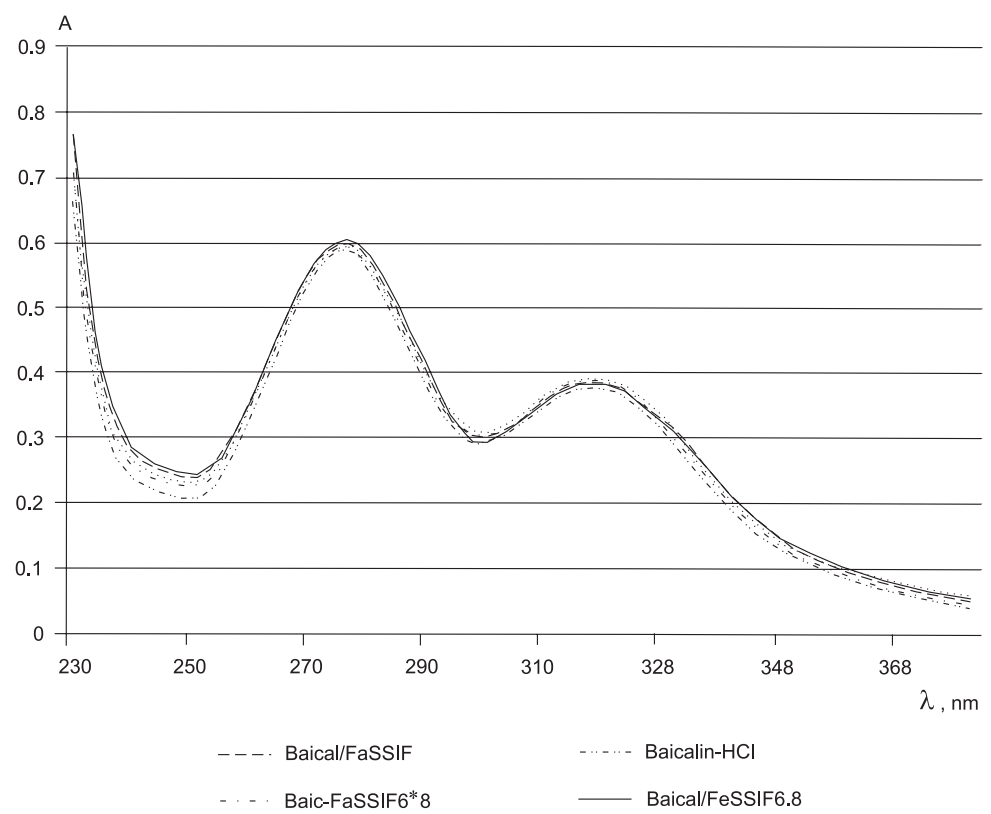

Baic-FaSSIF6.5

Fig. 1. Adsorption spectra of baicalin in $0.1 \mathrm{M}$ hydrochloric acid solution and biorelevant media FaSSIF (pH 6.5) and FeSSIF (pH 6.8)

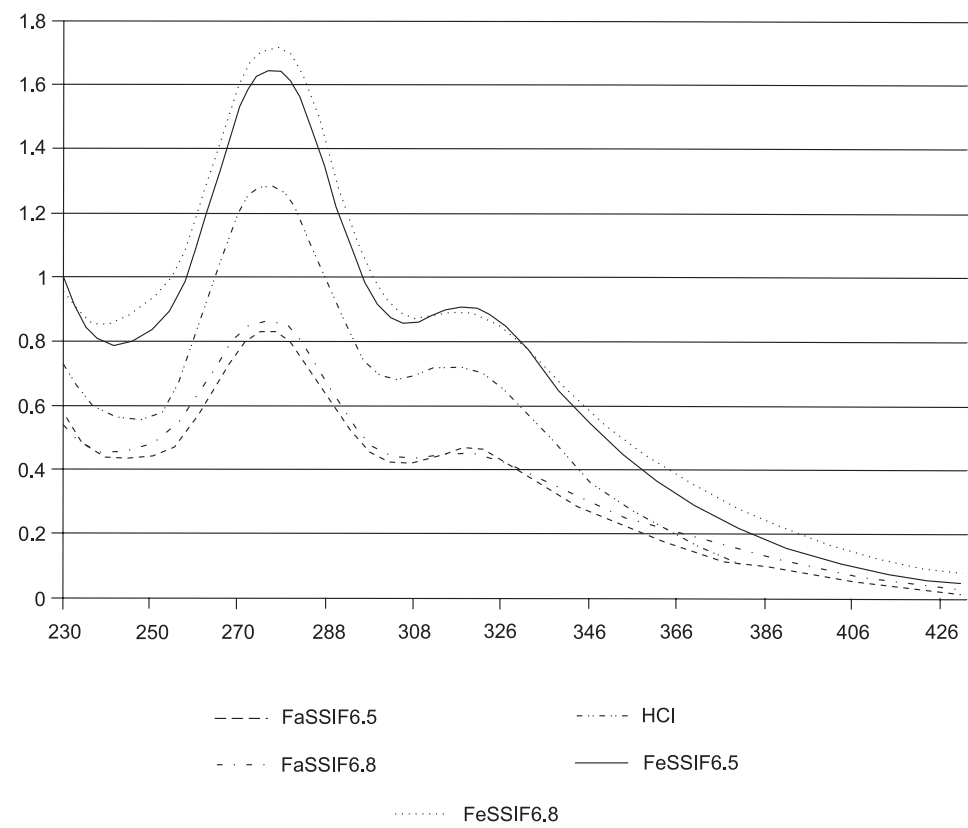

Fig. 2. Adsorption spectra of solutions obtained during extraction of the powder from Scutellaria baicalensis roots and rhizomes with $0.1 \mathrm{M}$ hydrochloric acid solution and biorelevant media FaSSIF and FeSSIF with pH 6.5 and 6.8

baicalensis roots and rhizomes with $0.1 \mathrm{M}$ hydrochloric acid solution and biorelevant media FaSSIF and FeSSIF with $\mathrm{pH}$ 6.5 and $\mathrm{pH} 6.8$ has shown that their structure is virtually the same as the spectral structure of baicalin solutions.

In all spectra in the range from $230 \mathrm{~nm}$ to $430 \mathrm{~nm}$ there are also two bands - the intensive absorption band of aromatic compounds with the maximum in the range of 274-276 nm and the less intensive, but broader band with the maximum in the range of 315-318 $\mathrm{nm}$. This band becomes less distinct due to the presence of the amount of compounds with the similar structure in the solution, but it is broad enough and can be used to measure the optical density in quantitative determination.
Thus, as a result of the experiment conducted to develop the spectrophotometric method for quantitative determination of the concentration of active ingredients of the powder from Scutellaria baicalensis roots and rhizomes the band in the near ultraviolet region with the maximum at $317 \mathrm{~nm}$ characterized by sufficient intensity and specificity was selected as the analytical absorption band.

In order to test the possible impact of the dissolution media on the total optical density at the analytical wavelength the adsorption spectra of biorelevant media FaSSIF and FeSSIF with pH 6.5 or 6.8 were studied (Fig. 3). The analysis of the data obtained has shown that the media are really not transparent in ultraviolet light and have 


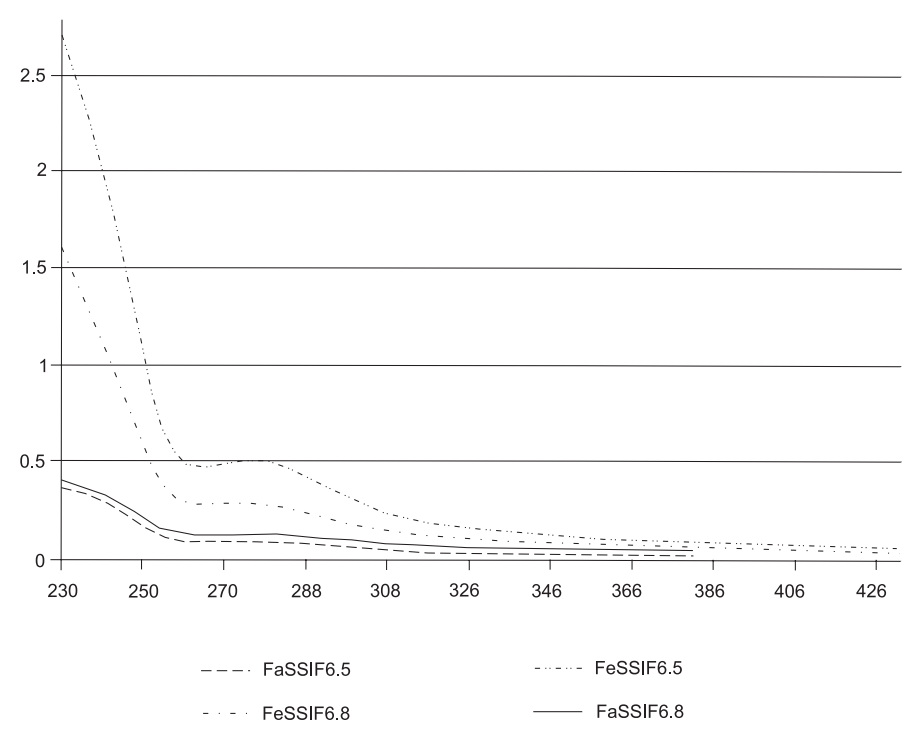

Fig. 3. Adsorption spectra of the biorelevant dissolution media

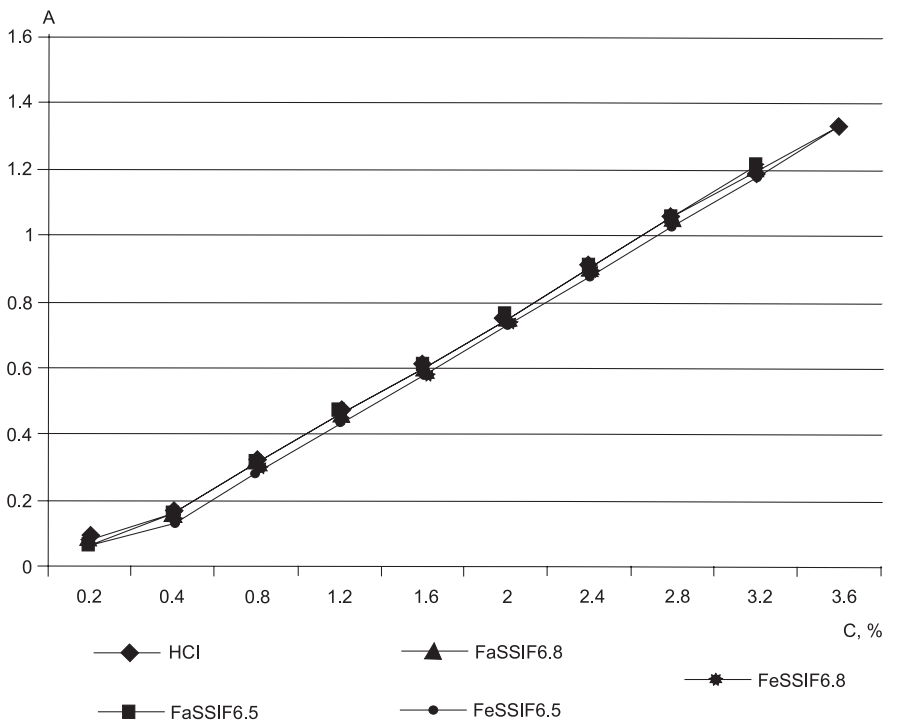

Fig. 4. The calibration curves of baicalin solutions in different dissolution media

quite intensive absorption in the range of 230-290 $\mathrm{nm}$. However, at $317 \mathrm{~nm}$ they have not any individual peaks. The proper choice of the analytical absorption band in the near ultraviolet region and the use of dissolution media as control solutions allow neutralizing their impact on the total optical density.

The absorbance testing of baicalin solutions in $0.1 \mathrm{M}$ hydrochloric acid solution and biorelevant media FaSSIF and FeSSIF with pH 6.5 and $\mathrm{pH} 6.8$ has shown that the dependence is linear and obeys the Beer-Lambert law in the range of the concentration from 0.4 to $3.6-4.0 \cdot 10^{-3} \%$ (Fig. 4).

The specific absorption rate $A_{1 \mathrm{~cm}}^{1 \%}$ in the concentration range mentioned is from 366 to 379 .

\section{CONCLUSIONS}

1. To develop the method for determining the concentration of solutions of pharmacologically active substances while studying bioavailability of capsules containing a finely divided powder of Scutellaria baicalensis roots and rhizomes the adsorption spectra of baicalin in $0.1 \mathrm{M}$ hydrochloric acid solution and biorelevant media FaSSIF and FeSSIF with pH of 6.5 and 68 have been studied. It has been found that the adsorption spectra of baicalin in the range from 230 to $370 \mathrm{~nm}$ consist of two absorption bands with the maxima at 276 and $317 \mathrm{~nm}$. The band in the near ultraviolet region is rather broad, intensive and can be promising for development of the spectrophotometric quantification method.

2 . The study of the effect of co-extractive substances on the total spectrum of powder extracts from Scutellaria baicalensis roots and rhizomes has shown that although the band with the maximum at $317 \mathrm{~nm}$ becomes less expressive, it can be used to quantify the amount of flavonoids in the extracts calculated with reference to baicalin using the one-component single-wave spectrophotometry by standard.

3. Biorelevant media FaSSIF and FeSSIF with $\mathrm{pH}$ 6.5 and 6.8 have not absorption maxima in the near ultraviolet region; they will not distort the results of quantitative determination of flavonoids in extracts at $317 \mathrm{~nm}$.

4. Determination of absorbance of baicalin solutions in $0.1 \mathrm{M}$ hydrochloric acid solution and biorelevant media FaSSIF and FeSSIF with pH 6.5 and $\mathrm{pH} 6.8$ has shown 
that the dependence is linear and obeys the Beer-Lambert law in the range of the concentration from 0.4 to $3.6-4.0 \cdot 10^{-3} \%$. The specific absorption rate $A_{1 c m}^{1 \%}$ in is in the range from 366 to 379 .

5. As a result, the possibility of spectrophotometric determination for the concentration of biologically ac- tive substances of the powder of Scutellaria baicalensis roots and rhizomes in solutions calculated with reference to baicalin when studying bioavailability of the capsules developed has been proven.

Conflict of Interests: authors have no conflict of interests to declare.

\section{REFERENCES}

1. Настанова з клінічних досліджень. Лікарські засоби. Дослідження біодоступності та біоеквівалентності : настанова МОЗ України від 07.01.2005 p. № 42. - К. : Моріон, 2005. - 22 с.

2. Оценка биофармацевтической растворимости (в условиях, моделирующих физиологические) лекарственных средств из перечня ЖНВЛП (обзор) / Т. А. Ярушок, И. Е. Шохин, Г. В. Раменская, А. Ю. Савченко // Биофармац. журн. - 2012. - Т. 4, № 2. - С. 25 -31.

3. WHO Technical Report Series 937, annex 8 "Proposal to waive in vivo bioequivalence requirements for WHO Model List of Essential Medicines immediate-release, solid oral dosage forms" // WHO Expert Committee on Specifications for Pharmaceutical Preparations. - 2006.

4. Биорелевантные среды растворения - современный инструмент для моделирования процессов растворения и всасывания ЛС / Е. А. Волкова, И. Е. Шохин, Г. В. Раменская и др. // Биомедицина. - 2011. - № 3. - С. 133-140.

5. Давыдова, К. С. Тест «Растворение» в контроле качества лекарственных средств / К. С. Давыдова, Ю. И. Кулинич, И. Е. Шохин // Ремедиум. - 2010. - № 5. - C. 42.

6. Gowthamarajan, K. Dissolution testing for poorly soluble drugs : a continuing perspective / K. Gowthamarajan // Dissolution Technol. 2010. - Vol. 17, Issue 3. - P. 24-32. doi: 10.14227/dt170310p24

7. AAPS Workshop on the Role of Dissolution in QbD and Drug Product Life Cycle : A Commentary / S. S. D'Souza, R. Lozano, S. Mayock, V. Gray // Dissolution Technol. - 2010. - Vol. 17, Issue 4. - P. 41-45. doi: 10.14227/dt170410p41

8. Сліпченко, Г. Д. Розробка препарату «Скутелла» у формі твердих желатинових капсул на основі шоломниці байкальської // Г. Д. Сліпченко, М. О. Казарінов, П. Д. Пашнєв // зб. наук. праць співроб. НМАПО імені П. Л. Шупика. - Вип. 18, Кн. 3. - К., 2009. - С. 391-395.

9. Сліпченко, Г. Д. Комплексна оцінка реологічних властивостей подрібненої сировини шоломниці байкальської / Г. Д. Сліпченко // Фармац. журн. - 2012. - № 5. - С. 58-62.

\section{REFERENCES}

1. Nastanova MOZ Ukrainu vid 07.01.2005 r. №42. Nastanova z klinichnykh doslidzhen. Likarski zasoby. Dosliszhennia biodostupnosti ta bioekvivalentnosti. Kyiv: Morion, 22.

2. Yarushok, T. A., Shokhin, I. E., Ramenskaiia, G. V., Savchenko, A. Yu. (2012). Biofarmatcevticheskii zhurnal, 4 (2), 25 - 31.

3. WHO Technical Report Series 937, annex 8 "Proposal to waive in vivo bioequivalence requirements for WHO Model List of Essential Medicines immediate-release, solid oral dosage forms". WHO Expert Committee on Specifications for Pharmaceutical Preparations (2006).

4. Volkova, E. A., Shokhin, I. E., Ramenskaia, G. V. et al. (2011). Biomeditcina, 3, 133-140.

5. Davydova, K. S., Kulinich, Yu. I., Shokhin, I. E. (2010). Remedium, 5, 42.

6. Gowthamarajan, K. (2010). Dissolution Testing for Poorly Soluble Drugs: A Continuing Perspective. Dissolution Technologies, 17 (3), 24-32. doi: 10.14227/dt170310p24

7. D'Souza, S. S., Lozano, R., Mayock, S., Gray, V. A. (2010). AAPS Workshop on the Role of Dissolution in QbD and Drug Product Life Cycle: A Commentary. Dissolution Technologies, 17 (4), 41-45. doi: 10.14227/dt170410p41

8. Slipchenko, H. D., Kazarinov, M. O., Pashniev, P. D. (2009). Rozrobka preparatu "Skutella" u formi tverdykh zhelatynovykh kapsul na osnovi sholomnytsi baikalskoi, 18 (3). Kyiv, 391-395.

9. Slipchenko, H. D. (2012). Farmatsevtychnyi zhurnal - Pharmaceutical Journal, 5, 58-62.

Information about authors:

Slipchenko G. D., Candidate of Pharmacy (Ph.D.), associate professor of the Department of Industrial Technology of Drugs, National University of Pharmacy.

E-mail: galinaslipchenko@ukr.net

Ruban O. A., Doctor of Pharmacy (Dr. habil.), professor, head of the Department of Industrial Technology of Drugs, National University of Pharmacy

Hrudko V. O., Candidate of Chemistry (Ph.D.), associate professor of the Department of Pharmaceutical Chemistry, National University of Pharmacy.

Відомості про авторів:

Сліпченко Г. Д., канд. фармац. наук, доцент кафедри заводської технології ліків, Національний фармацевтичний університет

E-mail: galinaslipchenko@ukr.net

Рубан О. А., д-р фармац. наук, професор, завідувач кафедри заводської технології ліків, Національний фармацевтичний університет

Грудько В. О., канд. фармац. наук, доцент кафедри фармацевтичної хімії, Національний фармацевтичний університет

Сведения об авторах:

Слипченко Г. Д., канд. фармац. наук, доцент кафедры заводской технологии лекарств, Национальный фармацевтический университет.

E-mail: galinaslipchenko@ukr.net

Рубан Е. А., д-р фармац. наук, профессор, зав. кафедры заводской технологии лекарств, Национальный фармацевтический университет

Грудько В. А., канд. фармац. наук, доцент кафедры фармацевтической химии, Национальный фармацевтический университет 